\title{
Revenue and operational, financial performance of the leading Indian automobile companies of India: A relational mutual analysis
}

\author{
Anis Ali ${ }^{\text {** }}$

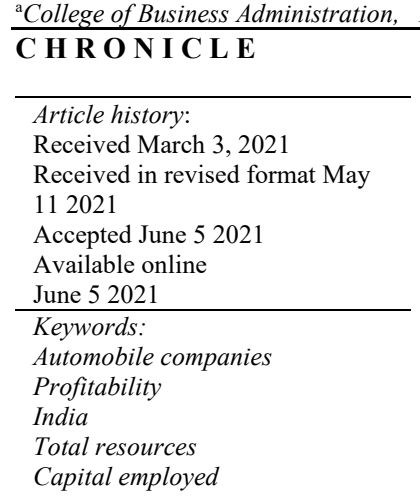

\section{Introduction}

The operational performance and financial performance measures the operational efficiency while the financial performance scales the financial soundness of the business organization. Operational efficiency refers to the velocity of the business activities or the profitability of the business organization. The velocity of the business activities indicates the utilization of the resources of the business organization. Profitability explains the profit earning capacity or cost efficiency while velocity sharpness or the turnover of the business activities. Jointly, the profitability and velocity of the business organization enhance the absolute amount of the profit. The financial soundness of the business organization refers to the paying capacity of debts of the business organization. There are two types of funds needed in the business organization i.e. funds to arrange the fixed assets and resources of the business organization and funds to operate or utilize the fixed assets and resources for the operation of business activities. The funds which are needed to manage the fixed assets or resources are called the capital employed while the fund needed to operate the business activities is called the working capital. The capital employed refers to the equity capital and long-term liabilities or long-term debts. The working capital which is involved in the operational

* Corresponding author

E-mail address: ah.ali@psau.edu.sa (A. Ali)

C 2022 Growing Science Ltd. All rights reserved.

doi: 10.5267/j.ac.2021.6.005 
or business activities is the excess of current assets over the current liabilities. The revenue of the business organization refers to the income generated through business activities or operational activities. The revenue of the business organization is the barometer to measure the level of operation and the relative study of revenue with other financial variables indicates the profitability and utilization of financial resources. The relationship of revenue and gross profit or net profit measures the profitability while the relationship of revenue and total resources or capital employed and working capital measures the utilization of resources and velocity of business activities. In India, the automobile sector is a prominent and growing sector and contributes to the economy. As it was seen that the revenue in the leading Indian automobile sector companies is significantly different for the period 2011 to 2020. So, the present study considers the mutual relationship between revenue and profitability, total resources, capital employed of higher and lower revenue Indian leading automobile companies.

\section{Literature Review}

Jamali and Asadi (2012) found a positive relationship between managerial efficiency and profitability and recommended the improvement of managerial efficiency for the enhancements of profitability. Ashraf (2012) observed the negative relationship between working capital and profitability. But there is a positive relationship between the size of and profitability of the various sectors. Gopalakrishnan (2014) found a negative trend in the working capital of the Indian automobile sector companies. He recommended the appropriate marketing strategy, cost reduction and revision of the sale prices of the products, and expansion in the range of the products to enhance the turnover and profit. Suresh and Sengottaiyan (2015) observed the positive and negative relationship between capital structure and profitability in leading Indian automobile companies. Tripathi and Rao (2016) observed the growth trend in the revenue of the passenger and twowheeler vehicles in the Indian automobile companies. Kumar and Kaur (2016) studied and found the mixed relationship between the size and profitability of Indian automobile companies for the period 1998 to 2014. Kaur \& Kaur (2016) assessed and studied the profitability of Indian automobile sector companies listed in the BSE (India) from 2003-04 to 2014. Liquidity, payment to creditors and proprietary position, growth of the firm, and manufacturing velocity govern the profitability. Jaisinghani and Tandon (2016) found a positive relationship between research and development and profitability in 105 Indian automobile companies of India for the period 2003 to 2013. There was a U Shaped relationship between profitability and research and development. Further, they recommended the optimum investment in the research in research and development activities. Hiran (2016) found that the operating and financial leverage of the Indian automobile companies negatively affects profitability. Arumugam, Kumar and Preetha (2016) revealed the contribution of the Indian automobile companies in the developing economy. Paliwal and Chouhan (2017) found a positive relationship between liquidity and profitability and suggested the optimum relationship between liquidity and profitability. Shajar (2017) found that the influence of cash conversion cycle and working capital on the profitability and recommended that the efficient management of working capital enhance the profitability of the Indian automobile companies. Gandhi (2017) explored the Indian automobile sector in the developing sector in the economy. Ranjithkumar and Eahambaram (2018) studied the Indian automobile companies listed in the BSE (India) and found that the financial performance is governed by the velocity of operational activities, liquidity position, and growth of the firms, and payment strategies and policies. Simlai and Guha (2019) revealed that the ratio of internal and external is 1:2 in Indian automobiles and affects the profitability. Kumar \& Choudhary (2019) explored that the governments' industrial policy and policy of taxation, investment affects the financial performance of automobile companies. Hassan \& Shrivastava (2019) studied the relationship between working capital and profitability and found the positivity in Indian automobile companies. Singh, Kashyap, Tomar, and Garg (2020) found that the Indian automobile industry is the most prominent in the Indian economy with a $7.64 \%$ growth per annum. There are challenges for new entrants for survival in the Indian automobile industry and enhance profit and profitability. Tripathi \& Talukder (2020) studied the mutual relationship of profitability and supply chain performance and found that the weaker supply chain performance affects the profitability more than the operational efficiency and utilization of resources. Swalih, Adarsh and Sulphey (2021) explored the strong financial soundness of the Indian automobile sector companies. Most of the studies reveal that the Indian automobile sector contributes to the Indian economy and working capital, research development, and supply chain performance, industrial policy and taxation, the velocity of operation and managerial efficiency affects the profitability of the Indian automobile companies. But there is no study available that explore the relationship of revenue and operational, financial governance of the leading Indian automobile companies of India.

\section{Research Methodology}

The research is based on the secondary data taken from the websites of the leading automobile companies of India for the period 2011 to 2020. Statistical tools were applied to establish the relationship between the financial variables of the Indian automobile companies to infer conclusions. The following formula applied to get the averages of the variables (Mean), degree and direction of the association (Rank correlation), variability (coefficient of variation) between the financial variables, and growth (FBI) of the Indian automobile companies:

Mean $=\frac{\text { Sum of the Financial variables }}{\text { Number of the Fiancial Variables }}$ 
Rank Correlation $\left(\mathrm{r}_{\mathrm{s}}\right)=1-\frac{6 \sum(D * D)}{n(n * n-1)}$

Co-efficient of variation $(\mathrm{CV})=\frac{\text { Mean }}{\text { Standard Deviation }}$

Fixed Base Index (FBI) = $=\frac{\text { Value of the financial varible in the current year }}{\text { Vale of the variable in the base year }} 100$

The average of the financial variables of the Indian automobile companies calculated to assign the ranks. The rank correlation was calculated between the associated variables of leading Indian automobile companies to get the degree and direction of the relationship (Ali, A., 2020). The coefficient of variation (CV) is calculated to get the comparative variability of variables of Indian automobile companies and facilitate the relational financial analysis. The fixed base index numbers of financial variables calculated to get the growth trend of Indian automobile companies (Ali, A., 2021).

\section{Interpretation and Data Analysis}

The interpretation and data analysis of the leading Indian automobile companies can be bifurcated into two categories to assess the growth and development.

1. Relational operational growth of leading Indian automobile companies

2. Relational financial growth of leading Indian automobile companies

\subsection{Relational operational growth of leading Indian automobile companies}

The relational operational growth is the relational analysis of the revenue and its variability, revenue and gross profitability, revenue, and variability of profitability of leading Indian automobile companies.

\subsubsection{Relational analysis of revenue and variability of revenue of leading Indian automobile companies}

The relational analysis of the revenue and its variability of the leading Indian automobile companies will reveal the relationship between the revenue and its impact on the variability.

Table 1

Relationship between Revenue and variability revenue of leading Indian automobile sector companies

\begin{tabular}{|c|c|c|c|c|c|c|c|c|}
\hline Years & Tata & Maruti & Mahindra & Hero & Bajaj & Ashok & TVS & Eicher \\
\hline 2011 & 125707 & 40102 & 25137 & 20774 & 16830 & 12034 & 6711 & 737 \\
\hline 2012 & 169878 & 38614 & 33893 & 25185 & 19827 & 13459 & 7580 & 1174 \\
\hline 2013 & 192419 & 48115 & 42875 & 25627 & 20618 & 13020 & 7633 & 1911 \\
\hline 2014 & 234470 & 47823 & 42575 & 27126 & 20727 & 10353 & 8545 & 3304 \\
\hline 2015 & 264283 & 53769 & 40579 & 29236 & 22013 & 14235 & 10632 & 4622 \\
\hline 2016 & 274175 & 63958 & 43151 & 30618 & 23448 & 19616 & 11953 & 6957 \\
\hline 2017 & 270298 & 76141 & 46709 & 30541 & 22695 & 21055 & 13064 & 7914 \\
\hline 2018 & 289386 & 80337 & 48872 & 32231 & 25099 & 26242 & 15310 & 9168 \\
\hline 2019 & 299191 & 83027 & 52961 & 33125 & 29567 & 28614 & 17913 & 9715 \\
\hline 2020 & 258594 & 71690 & 44898 & 28408 & 29112 & 17267 & 16074 & 9009 \\
\hline Mean & 237840 & 60357 & 42165 & 28287 & 22994 & 17590 & 11542 & 5451 \\
\hline SD & 56952 & 16790 & 7833 & 3725 & 4016 & 6192 & 3971 & 3517 \\
\hline $\mathrm{CV}$ & 24 & 28 & 19 & 13 & 17 & 35 & 34 & 65 \\
\hline Revenue Mean(R1) & 1 & 2 & 3 & 4 & 5 & 6 & 7 & 8 \\
\hline Rank-CV(R2) & 5 & 4 & 6 & 8 & 7 & 2 & 3 & 1 \\
\hline $\mathrm{D}^{2}$ (R1-R2) & 16 & 4 & 9 & 16 & 4 & 16 & 16 & 49 \\
\hline & & \multicolumn{7}{|c|}{$\sum \mathrm{D} 2=130$} \\
\hline
\end{tabular}

Source: Author's own calculation based on data contained in the financial statements of the concerned Indian automobile companies.

$\mathrm{r}_{\mathrm{s}}=1-\frac{6 \sum(D * D)}{n(n \times n-1)}=1-\frac{6 \sum(130)}{8(8 \times 8-1)}=-0.55$

From Table 1 it is obvious that there is a moderate negative relation between the absolute revenue and the variability of the revenue for the period 2011 to 2020. Indian automobile companies whose absolute revenue is comparatively low have the highest positive trend of growth of absolute revenue.

\subsubsection{Relational analysis of revenue and gross profitability of leading Indian automobile companies}

The relational analysis of the revenue and gross profitability of the leading Indian automobile companies will reveal the relationship between the revenue and its impact on the gross profitability.

$\mathrm{r}_{\mathrm{s}}=1-\frac{6 \sum(D * D)}{n(n \times n-1)}=1-\frac{6 \sum(99)}{8(8 \times 8-1)}=-0.18$ 
From Table 2 it is obvious that there is a low degree and negative relation between the absolute revenue and the gross profitability for the period 2011 to 2020 . Indian automobile companies whose absolute revenue is comparatively low have the highest positive trend of growth of profitability.

Table 2

Relationship between Revenue and Gross profitability of leading Indian automobile sector companies (2011-2020)

\begin{tabular}{|c|c|c|c|c|c|c|c|c|}
\hline Statistical tools & Tata & MSIL & M\&M L & Hero & Bajaj & Ashok & TVS & Eicher \\
\hline Mean-Revenue & 237840 & 60357 & 42165 & 28287 & 22994 & 17590 & 11542 & 5451 \\
\hline Rank-Revenue(R1) & 1 & 2 & 3 & 4 & 5 & 6 & 7 & 8 \\
\hline Mean-gross ptly & 7.505 & 14.508 & 14.27 & 14.598 & 23.373 & 9.438 & 7.392 & 29.204 \\
\hline Rank- Gross Ptlty (R2) & 7 & 4 & 5 & 3 & 2 & 6 & 8 & 1 \\
\hline $\mathrm{D}^{2}=(\mathrm{R} 1-\mathrm{R} 2)^{2}$ & 36 & 4 & 4 & 1 & 4 & 0 & 1 & 49 \\
\hline
\end{tabular}

Source: Author's calculation based on data contained in the financial statements of the concerned Indian automobile companies (Table $1 \&$ Appendix 1).

\subsubsection{Relational analysis of revenue and variability of gross profitability of leading Indian automobile companies}

The relational analysis of the revenue and variability of gross profitability of the leading Indian automobile companies will reveal the relationship between the revenue and its impact on the gross profitability.

Table 3

Relationship between revenue and variability of gross profitability of leading Indian automobile sector companies (20112020)

\begin{tabular}{|c|c|c|c|c|c|c|c|c|}
\hline Statistical tools & Tata & MSIL & M\&M L & Hero & Bajaj & Ashok & TVS & Eicher \\
\hline Mean-Revenue & 237840 & 60357 & 42165 & 28287 & 22994 & 17590 & 11542 & 5451 \\
\hline Rank-Revenue(R1) & 1 & 2 & 3 & 4 & 5 & 6 & 7 & 8 \\
\hline CV of gross ptly & 45 & 21 & 10 & 20 & 7 & 33 & 13 & 20 \\
\hline Rank- CV of gross ptlty (R2) & 1 & 3 & 7 & 4.5 & 8 & 2 & 6 & 4.5 \\
\hline $\mathrm{D}^{2}=(\mathrm{R} 1-\mathrm{R} 2)^{2}$ & 0 & 1 & 16 & 0.25 & 9 & 64 & 1 & 12.25 \\
\hline \multicolumn{9}{|c|}{$\sum \mathrm{D}^{2}=91.25$} \\
\hline
\end{tabular}

Source: Author's calculation based on data contained in the financial statements of the concerned Indian automobile companies (Table $1 \&$ Appendix 1)

$r_{\mathrm{s}}=1-\frac{6 \sum(D \times D)}{n(n \times n-1)}=1-\frac{6 \sum(91.25)}{8(8 \times 8-1)}=-0.09$

From Table 3 it is obvious that there is a very low degree negative relation between the absolute revenue and the variability of gross profitability for the period 2011 to 2020. Indian automobile companies whose absolute revenue is comparatively low have the highest positive trend of the variability of profitability.

\subsection{Relational financial growth of leading Indian automobile companies}

The relational financial growth is the relational analysis of the revenue and total resources, revenue and variability total resources, revenue and growth total resources, revenue and capital employed, revenue and growth of capital employed of leading Indian automobile companies.

\subsubsection{Relational analysis of revenue and total resources of leading Indian automobile sector companies}

The relational analysis of the revenue and total resources of the leading Indian automobile companies will reveal the relationship between the revenue and total resources.

Table 4

Relationship between revenue and total resources of leading Indian automobile sector companies (2011-2020). (Rs. in Cr.)

\begin{tabular}{|c|c|c|c|c|c|c|c|c|}
\hline Statistical tools & Tata & MSIL & M\&M L & Hero & Bajaj & Ashok & TVS & Eicher \\
\hline Mean-Revenue & 237840 & 60357 & 42165 & 28287 & 22994 & 17590 & 11542 & 5451 \\
\hline Rank-Revenue(R1) & 1 & 2 & 3 & 4 & 5 & 6 & 7 & 8 \\
\hline Mean-total resources & 55884 & 40959 & 36122 & 13104 & 17639 & 14049 & 5305 & 4726 \\
\hline Rank- total resources (R2) & 1 & 2 & 3 & 6 & 4 & 5 & 7 & 8 \\
\hline $\mathrm{D}^{2}=(\mathrm{R} 1-\mathrm{R} 2)^{2}$ & 0 & 0 & 0 & 4 & 1 & 1 & 0 & 0 \\
\hline
\end{tabular}

Source: Author's calculation based on data contained in the financial statements of the concerned Indian automobile companies (Table $1 \&$ Appendix 2 )

$\mathrm{r}_{\mathrm{s}}=1-\frac{6 \sum(D \times D)}{n(n \times n-1)}=1-\frac{6 \sum(6)}{8(8 * 8-1)}=0.93$

From Table 4 it is obvious that there is a high degree and positive relation between the absolute revenue and the total resources for the period 2011 to 2020 . Indian automobile companies whose absolute total resources are comparatively high 
have the highest positive impact on absolute revenue. The total resources proportionately and positively govern the absolute revenue of the leading Indian automobile sector companies of India.

\subsubsection{Relational analysis of revenue and variability of total resources of leading Indian automobile sector companies}

The relational analysis of the revenue and variability of total resources of the leading Indian automobile companies will reveal the relationship between the revenue and variability of total resources, and the impact of the variability of total resources on absolute revenue.

Table 5

Relationship between revenue and variability of total resources of leading Indian automobile sector companies (2011-2020)

\begin{tabular}{|c|c|c|c|c|c|c|c|c|}
\hline Statistical tools & Tata & MSIL & M\&M L & Hero & Bajaj & Ashok & TVS & Eicher \\
\hline Mean-Revenue & 237840 & 60357 & 42165 & 28287 & 22994 & 17590 & 11542 & 5451 \\
\hline Rank-Revenue(R1) & 1 & 2 & 3 & 4 & 5 & 6 & 7 & 8 \\
\hline $\mathrm{CV}$ of TR & 8 & 42 & 31 & 27 & 35 & 18 & 44 & 80 \\
\hline Rank- CV of TR (R2) & 8 & 3 & 5 & 6 & 4 & 7 & 2 & 1 \\
\hline $\mathrm{D}^{2}=(\mathrm{R} 1-\mathrm{R} 2)^{2}$ & 49 & 1 & 4 & 4 & 1 & 1 & 25 & 49 \\
\hline
\end{tabular}

Source: Author's calculation based on data contained in the financial statements of the concerned Indian automobile companies (Table $1 \&$ Appendix 2)

$\mathrm{r}_{\mathrm{s}}=1-\frac{6 \sum(D * D)}{n(n \times n-1)}=1-\frac{6 \sum(134)}{8(8 \times 8-1)}=-0.60$

From Table 5 it is obvious that there is a moderate negative relationship between the absolute revenue and the variability of total resources for the period 2011 to 2020. Indian automobile companies whose variability of absolute total resources is comparatively high have a low negative impact on absolute revenue. The movement of total resources negatively governs the absolute revenue of the leading Indian automobile sector companies of India.

\subsubsection{Relational analysis of revenue and growth of total resources of leading Indian automobile sector companies}

The relational analysis of the revenue and growth of total resources of the leading Indian automobile companies will reveal the relationship between the revenue and growth of total resources, and the impact of the growth of total resources on absolute revenue.

Table 6

Relationship between revenue and growth of total resources of leading Indian automobile sector companies (2011-2020)

(Rs. in Cr.)

\begin{tabular}{|c|c|c|c|c|c|c|c|c|}
\hline Statistical tools & Tata & MSIL & M\&M L & Hero & Bajaj & Ashok & TVS & Eicher \\
\hline Mean-Revenue & 237840 & 60357 & 42165 & 28287 & 22994 & 17590 & 11542 & 5451 \\
\hline Rank-Revenue(R1) & 1 & 2 & 3 & 4 & 5 & 6 & 7 & 8 \\
\hline Mean-FBI of TR & 103 & 222 & 185 & 122 & 191 & 133 & 186 & 544 \\
\hline Rank- FBI of TR (R2) & 8 & 2 & 5 & 7 & 3 & 6 & 4 & 1 \\
\hline $\mathrm{D}^{2}=(\mathrm{R} 1-\mathrm{R} 2)^{2}$ & 49 & 0 & 4 & 9 & 4 & 0 & 9 & 49 \\
\hline
\end{tabular}

Source: Author's calculation based on data contained in the financial statements of the concerned Indian automobile companies (Table $1 \&$ Appendix 3 ).

$\mathrm{r}_{\mathrm{s}}=1-\frac{6 \sum(D * D)}{n(n \times n-1)}=1-\frac{6 \sum(126)}{8(8 \times 8-1)}=-0.48$

From Table 6 it is obvious that there is a moderate negative relationship between the absolute revenue and the growth of total resources for the period 2011 to 2020. Indian automobile companies whose growth of absolute total resources is comparatively high have a low negative impact on absolute revenue. The growth of total resources negatively governs the absolute revenue of the leading Indian automobile sector companies of India.

\subsubsection{Relational analysis of revenue and capital employed of leading Indian automobile sector companies}

The relational analysis of the revenue and capital employed of the leading Indian automobile companies will reveal the relationship between the revenue and capital employed in business activities, and the impact of capital employed on absolute revenue.

Table 7

Relationship between revenue and capital employed of leading Indian automobile sector companies (2011-2020). (Rs. in Cr.)

\begin{tabular}{|c|c|c|c|c|c|c|c|c|}
\hline Statistical tools & Tata & MSIL & M\&M L & Hero & Bajaj & Ashok & TVS & Eicher \\
\hline Mean-Revenue & 237840 & 60357 & 42165 & 28287 & 22994 & 17590 & 11542 & 5451 \\
\hline Rank-Revenue(R1) & 1 & 2 & 3 & 4 & 5 & 6 & 7 & 8 \\
\hline Mean-total resources & 34418 & 31025 & 26391 & 8761 & 13534 & 8105 & 2802 & 3162 \\
\hline Rank- total resources (R2) & 1 & 2 & 3 & 5 & 4 & 6 & 8 & 7 \\
\hline $\mathrm{D}^{2}=(\mathrm{R} 1-\mathrm{R} 2)^{2}$ & 0 & 0 & 0 & 1 & 1 & 0 & 1 & 1 \\
\hline
\end{tabular}

Source: Author's calculation based on data contained in the financial statements of the concerned Indian automobile companies (Table 1 \& Appendix 4). 
$\mathrm{r}_{\mathrm{s}}=1-\frac{6 \sum(D * D)}{n(n * n-1)}=1-\frac{6 \sum(4)}{8(8 * 8-1)}=0.95$

From Table 7 it is obvious that there is a high degree and positive relation between the absolute revenue and the capital employed for the period 2011 to 2020. Indian automobile companies whose capital employed is comparatively high have the highest positive impact on absolute revenue. The capital employed proportionately and positively governs the absolute revenue of the leading Indian automobile sector companies of India.

\subsubsection{Relational analysis of revenue and growth of capital employed of leading Indian automobile sector companies}

The relational analysis of the revenue and growth capital employed of the leading Indian automobile companies will reveal the relationship between the revenue and capital employed in business activities, and the impact of the growth of capital employed on absolute revenue.

Table 8

Relationship between revenue and growth of capital employed of leading Indian automobile sector companies (2011-2020)

\begin{tabular}{|c|c|c|c|c|c|c|c|c|}
\hline Statistical tools & Tata & MSIL & M\&M L & Hero & Bajaj & Ashok & TVS & Eicher \\
\hline Mean-Revenue & 237840 & 60357 & 42165 & 28287 & 22994 & 17590 & 11542 & 5451 \\
\hline Rank-Revenue(R1) & 1 & 2 & 3 & 4 & 5 & 6 & 7 & 8 \\
\hline Mean-FBI of CE & 98 & 215 & 194 & 186 & 251 & 119 & 166 & 569 \\
\hline Rank- FBI of CE (R2) & 8 & 3 & 4 & 5 & 2 & 7 & 6 & 1 \\
\hline $\mathrm{D}^{2}=(\mathrm{R} 1-\mathrm{R} 2)^{2}$ & 49 & 1 & 1 & 1 & 9 & 1 & 1 & 49 \\
\hline
\end{tabular}

Source: Author's own calculation based on data contained in the financial statements of the concerned Indian automobile companies (Table $1 \& 5$ ).

$\mathrm{r}_{\mathrm{s}}=1-\frac{6 \sum(D * D)}{n(n * n-1)}=1-\frac{6 \sum(112)}{8(8 * 8-1)}=-0.33$

From Table 8 it is obvious that there is a moderate negative relationship between the absolute revenue and the growth of capital employed for the period 2011 to 2020. Indian automobile companies whose growth of capital employed is comparatively high have a low negative impact on absolute revenue. The growth of capital employed negatively governs the absolute revenue of the leading Indian automobile sector companies of India.

\subsubsection{Relational analysis of revenue and growth variability of capital employed of leading Indian automobile sector companies}

The relational analysis of the revenue and growth variability of capital employed of the leading Indian automobile companies will reveal the relationship between the revenue and capital employed in business activities, and the impact of growth variability of capital employed on absolute revenue.

Table 9

Relationship between revenue and growth variability of capital employed of leading Indian automobile sector companies (2011-2020)

\begin{tabular}{|c|c|c|c|c|c|c|c|c|}
\hline Statistical tools & Tata & MSIL & M\&M L & Hero & Bajaj & Ashok & TVS & Eicher \\
\hline Mean-Revenue & 237840 & 60357 & 42165 & 28287 & 22994 & 17590 & 11542 & 5451 \\
\hline Rank-Revenue(R1) & 1 & 2 & 3 & 4 & 5 & 6 & 7 & 8 \\
\hline $\mathrm{CV}$ of $\mathrm{CE}$ & 9 & 44 & 34 & 43 & 46 & 11 & 39 & 90 \\
\hline Rank- CV of CE (R2) & 8 & 3 & 6 & 4 & 2 & 7 & 5 & 1 \\
\hline $\mathrm{D}^{2}=(\mathrm{R} 1-\mathrm{R} 2)^{2}$ & 49 & 1 & 9 & 0 & 9 & 1 & 4 & 49 \\
\hline
\end{tabular}

Source: Author's own calculation based on data contained in the financial statements of the concerned Indian automobile companies (Table $1 \&$ Appendix 4).

$\mathrm{r}_{\mathrm{s}}=1-\frac{6 \sum(D * D)}{n(n * n-1)}=1-\frac{6 \sum(122)}{8(8 * 8-1)}=-0.45$

From Table 9 it is obvious that there is a moderate negative relationship between the absolute revenue and the growth variability of capital employed for the period 2011 to 2020. Indian automobile companies whose growth variability of capital employed is comparatively high have a low negative impact on absolute revenue. The growth variability of capital employed negatively governs the absolute revenue of the leading Indian automobile sector companies of India.

\section{Results}

Based on the above analysis and interpretations it can be concluded regarding the financial growth and development of the leading Indian automobile companies of India. The leading Indian automobile companies whose revenue is comparatively 
low have the highest positive trend of growth of absolute revenue, profitability, and positive variability of profitability. It indicates that the smaller Indian automobile companies are operationally growing positively than the bigger Indian automobile companies. The total resources and capital employed positively and proportionately govern the absolute revenue of the leading Indian automobile companies. The investment in the total resources or investment in capital employed directly affects the revenue of the Indian automobile companies. Indian automobile companies whose variability of absolute total resources, growth of absolute total resources, growth of capital employed, growth variability of capital employed are comparatively high have a low negative impact on absolute revenue. The movement of total resources and capital employed negatively governs the absolute revenue of the leading Indian automobile sector companies of India.

\section{Discussion}

There is remarkable growth seen in the Indian automobile companies whose revenue or turnover is low. This refers to the maximum utilization of resources and salability of automobile products of smaller Indian automobile companies. There is a positive trend seen in the low revenue Indian automobile companies refers to the potentials to further investments in production level. The profit margin i.e. gross profitability of the smaller Indian automobile companies is higher than the higher revenue Indian automobile companies. This growth or variability of growth indicates that smaller automobile companies' products are much more salable that than the higher revenue Indian automobile companies. Total resources and capital employed in the business activities directly and proportionately governs the revenue of the Indian automobile companies. After reading the growth variability of revenue and governance of the revenue by the total resources and capital employed of the Indian automobile companies it can be concluded that the growth of profitability is only due to high contribution or high margin of the profitable products. The reason for the high margin of the profit is the low cost of production in smaller Indian automobile companies comparatively in higher revenue Indian automobile companies. The variability of absolute total resources, growth of absolute total resources, and growth of capital employed, growth variability of capital employed negatively governs the absolute revenue of the Indian automobile companies. This refers to the total resources and capital employed that governs the absolute revenue. But, in higher revenue Indian automobile companies, the growth trend is negative while in smaller Indian automobile companies the trend is positive.

\section{Conclusion}

From the above results and discussion, it can be concluded that the profitability of the smaller leading Indian automobile companies is better than the higher revenue companies. The growth of the profitability of the lower revenue leading Indian automobile is higher than the higher revenue Indian automobile companies. This refers to studying the profitability and cost composition of the products of the automobile and enhancing the production of the high profitability automobile products. The investment in total resources and capital employed is also beneficial in the lower revenue Indian automobile companies. Although, total resources and capital employed governs the revenue of the leading Indian automobile companies. The growth revenue in the context of total resources in total resources and capital employed is better in smaller leading automobile companies. So, there is a need to consider the automobile products of the higher revenue Indian automobile companies. In higher revenue Indian automobile companies, there is a need to consider the cost composition of the products. There should be special consideration of the direct cost of automobile products to control the cost of the higher revenue companies. The smaller leading automobile companies can enhance their absolute profit by enhancing their level of production.

\section{References}

Ali, A. (2020). Financial performance and size determinants: growth trend and similarity analysis of Indian pharmaceutical industry. Humanities \& Social Sciences Reviews, 8(4), 547-560.

Ali, A. (2021). Profitability variations and disparity in automobile sector: A case of leading Indian Automobile companies. Accounting, 7(6), 1455-1462.

Arumugam, D., Kumar, A. M., \& Preetha, R. (2016). Factors Determining Profitability in Indian Automobile Industry. Indian Journal of Commerce and Management Studies, 7(2), 64-69.

Ashraf, C. K. (2012). The relationship between working capital efficiency and profitability. Journal of Accounting and Management, 2(3),21-45.

Gandhi, K. (2017). Profitability Analysis of Select Automobile Companies in India-With Special Reference to Tata Motors and Mahindra and Mahindra. SJCC Management Research Review, 7(2), 82-90.

Gopalakrishnan, C. (2014). Profitability Trend in BSE Listed Automobile Sector in India. RVS Journal of Management,6(2), 85-95.

Hassan, M., \& Shrivastava, S. K. (2019). Working Capital Management and Its Impact on the Profitability of Tata Motors. In Proceedings of 10th International Conference on Digital Strategies for Organizational Success. https://dx.doi.org/10.2139/ssrn.3308602

Hiran, S. (2016). Financial Performance Analysis of Indian Companies Belongs to Automobile Industry with Special Reference to Liquidity \& Leverage. International Journal of Multidisciplinary and Current Research, 4, 39-51.

Jaisinghani, D., \& Tandon, D. (2016). R\&D, Profit persistence impact on profitability of the Indian automobile sector. $A P E A$ $2016,1-43$. 
Jamali, A. H., \& Asadi, A. (2012). Management efficiency and profitability in Indian automobile industry: From theory to practice. Indian Journal of Science and Technology, 5(5), 2779-2781.

Kaur, N., \& Kaur, J. (2016). Determinants of profitability of automobile industry in India. Journal of Commerce \& Accounting Research, 5(3), 32-39.

Kumar, N., \& Choudhary, P. (2019). A Study of the Structure, Conduct and Performance of Indian Automobile Industry. Empirical Economic Letters, 18(9), 303-310.

Kumar, N., \& Kaur, K. (2016). Firm size and profitability in Indian automobile industry: An analysis. Pacific Business Review International, 8(7), 69-78.

Paliwal, R., \& Chouhan, V. (2017). Relationship between Liquidity and Profitability in Indian Automobile Industry. International Journal of Science and Research (IJSR ISSN (Online): 2319-7064.

Ranjithkumar, M.S. \& Eahambaram, C. (2018). A study on profitability analysis of Indian selected automobile industry in India. International Journal for Research in Engineering Application \& Management, 2(7), 412-416.

Shajar, S. N. (2017). Relationship between Working Capital Management and Profitability of Automobile Companies in India: A Paradigm Shift towards Economic Strengthening. International Journal of Trade, Economics and Finance, 8(4), 210-216

Simlai, D., \& Guha, M. (2019). Financial stability, profitability and growth analysis: a study on select indian automobile companies. Journal of Commerce \& Accounting Research, 8(1),21-34.

Singh, G., Kashyap, S., Tomar, K. S., \& Garg, V. (2020). A Study of Business Performance Management in Special Reference to Automobile Industry. In Data Management, Analytics and Innovation (pp. 69-92). Springer, Singapore.

Suresh, S., \& Sengottaiyan, A. (2015). Does Capital Structure Decision Affects Profitability? A Study of Selected Automobile Companies in India. International Journal of Research in Social Sciences, 5(4), 113-123.

Swalih, M., Adarsh, K., \& Sulphey, M. (2021). A study on the financial soundness of Indian automobile industries using Altman Z-Score. Accounting, 7(2), 295-298.

Tripathi, S., \& Talukder, B. (2020). Supply chain performance and profitability in Indian automobile industry: Evidence of segmental difference. Global Business Review, 1-22. DOI: 10.1177/0972150919898302

Tripathi, V., \& Rao, K. B. (2016). Progress Card of the Indian Automobile Industry. IUP Journal of Business Strategy, 13(3), 48-61

\section{Appendices}

\section{Appendix 1}

Gross profitability and its variability of Indian Automobile sector companies

\begin{tabular}{|c|c|c|c|c|c|c|c|c|}
\hline Years & Tata & MSIL & M\&M L & Hero & Bajaj & Ashok & TVS & Eicher \\
\hline 2020 & 1.66 & 14.18 & 16.41 & 16.42 & 22.82 & 7.42 & 8.39 & 31.05 \\
\hline 2019 & 10.82 & 15.76 & 15.53 & 16.7 & 21.92 & 11.17 & 7.91 & 35.24 \\
\hline 2018 & 8.27 & 17.68 & 14.91 & 18.01 & 24.36 & 11.98 & 8.42 & 35.56 \\
\hline 2017 & 5.84 & 18.59 & 13.3 & 18.09 & 25.93 & 11.61 & 8.49 & 34.57 \\
\hline 2016 & 10.15 & 17.98 & 13.38 & 16.91 & 25.92 & 12.52 & 8.22 & 32.19 \\
\hline 2015 & 1.77 & 15.09 & 12.89 & 12.66 & 21.74 & 8.48 & 6.3 & 30.69 \\
\hline 2014 & 8.52 & 13.54 & 13.42 & 11.39 & 23.88 & 2.34 & 6.38 & 28.03 \\
\hline 2013 & 8.48 & 11.56 & 13 & 10.69 & 22.15 & 7.52 & 6.12 & 23.13 \\
\hline 2012 & 8.74 & 9.38 & 13.29 & 12.23 & 22.16 & 10.09 & 6.89 & 18.22 \\
\hline 2011 & 10.8 & 11.32 & 16.57 & 12.88 & 22.85 & 11.25 & 6.8 & 23.36 \\
\hline Mean & 7.505 & 14.508 & 14.27 & 14.598 & 23.373 & 9.438 & 7.392 & 29.204 \\
\hline SD & 3.38 & 3.11 & 1.45 & 2.88 & 1.58 & 3.10 & 0.98 & 5.90 \\
\hline $\mathrm{CV}$ & 0.45 & 0.21 & 0.10 & 0.20 & 0.07 & 0.33 & 0.13 & 0.20 \\
\hline
\end{tabular}

Source: Author's own calculation based on data contained in the financial statements of the concerned Indian automobile companies.

\section{Appendix 2}

Total Resources and its variability of Indian Automobile sector companies.(Rs. in Cr.)

\begin{tabular}{|c|c|c|c|c|c|c|c|c|}
\hline Years & Tata & MSIL & M\&M L & Hero & Bajaj & Ashok & TVS & Eicher \\
\hline 2011 & 54190 & 18425 & 19540 & 10726 & 9248 & 10593 & 2858 & 782 \\
\hline 2012 & 54519 & 22302 & 23912 & 9889 & 11081 & 11916 & 3141 & 1024 \\
\hline 2013 & 52185 & 26734 & 27454 & 9642 & 12479 & 13097 & 3119 & 1483 \\
\hline 2014 & 49734 & 30536 & 31289 & 10097 & 14748 & 12808 & 3565 & 2229 \\
\hline 2015 & 49943 & 33551 & 32945 & 10522 & 15562 & 13311 & 4604 & \\
\hline 2016 & 56676 & 41940 & 35500 & 12341 & 16487 & 12774 & 4952 & 3624 \\
\hline 2017 & 58878 & 51251 & 39968 & 14694 & 20815 & 14040 & 5905 & 5540 \\
\hline 2018 & 59212 & 59370 & 47417 & 16739 & 23819 & 17336 & 7179 & 7795 \\
\hline 2019 & 60910 & 62932 & 52697 & 17641 & 27380 & 18224 & 8369 & 9477 \\
\hline 2020 & 62590 & 62552 & 50502 & 18749 & 24773 & 16390 & 9361 & 10579 \\
\hline Mean & 55884 & 40959 & 36122 & 13104 & 17639 & 14049 & 5305 & 4726 \\
\hline sd & 4502 & 17051 & 11338 & 3535 & 6219 & 2468 & 2329 & 3777 \\
\hline $\mathrm{cv}$ & 8 & 42 & 31 & 27 & 35 & 18 & 44 & 80 \\
\hline
\end{tabular}

Source: Author's own calculation based on data contained in the financial statements of the concerned Indian automobile companies. 
Appendix 3

Growth of total Resources (FBI) of Indian Automobile sector companies.

\begin{tabular}{|c|c|c|c|c|c|c|c|c|}
\hline Years & Tata & MSIL & M\&M L & Hero & Bajaj & Ashok & TVS & Eicher \\
\hline 2011 & 100 & 100 & 100 & 100 & 100 & 100 & 100 & 100 \\
\hline 2012 & 101 & 121 & 122 & 92 & 120 & 112 & 110 & 131 \\
\hline 2013 & 96 & 145 & 141 & 90 & 135 & 124 & 109 & 190 \\
\hline 2014 & 92 & 166 & 160 & 94 & 159 & 121 & 125 & 285 \\
\hline 2015 & 92 & 182 & 169 & 98 & 168 & 126 & 161 & 0 \\
\hline 2016 & 105 & 228 & 182 & 115 & 178 & 121 & 173 & 463 \\
\hline 2017 & 109 & 278 & 205 & 137 & 225 & 133 & 207 & 708 \\
\hline 2018 & 109 & 322 & 243 & 156 & 258 & 164 & 251 & 996 \\
\hline 2019 & 112 & 342 & 270 & 164 & 296 & 172 & 293 & 1211 \\
\hline 2020 & 115 & 339 & 258 & 175 & 268 & 155 & 328 & 1352 \\
\hline Mean & 103 & 222 & 185 & 122 & 191 & 133 & 186 & 544 \\
\hline
\end{tabular}

Source: Author's own calculation based on data contained in the financial statements of the concerned Indian automobile companies

\section{Appendix 4}

Capital employed and its variability of Indian Automobile sector companies. (Rs. in Cr.)

\begin{tabular}{|c|c|c|c|c|c|c|c|c|}
\hline Years & Tata & MSIL & M\&M L & Hero & Bajaj & Ashok & TVS & Eicher \\
\hline 2011 & 35190 & 14406 & 13588 & 4710 & 5392 & 6833 & 1692 & 555 \\
\hline 2012 & 32342 & 15755 & 16552 & 5547 & 6456 & 7072 & 1795 & 648 \\
\hline 2013 & 31080 & 20007 & 19303 & 5471 & 8345 & 7801 & 1865 & 848 \\
\hline 2014 & 30937 & 22462 & 22522 & 5674 & 10017 & 8221 & 2036 & 1272 \\
\hline 2015 & 29573 & 24728 & 23971 & 6638 & 11086 & 8276 & 2361 & \\
\hline 2016 & 37974 & 30901 & 25655 & 8292 & 13706 & 7884 & 2636 & 2422 \\
\hline 2017 & 37340 & 38024 & 30334 & 10601 & 17602 & 7618 & 3054 & 4058 \\
\hline 2018 & 34993 & 43928 & 34094 & 12395 & 19708 & 8517 & 3400 & 5600 \\
\hline 2019 & 37969 & 48782 & 38363 & 13511 & 22507 & 9435 & 4328 & 7499 \\
\hline 2020 & 36779 & 51257 & 39529 & 14773 & 20520 & 9391 & 4850 & 8718 \\
\hline MEAN & 34418 & 31025 & 26391 & 8761 & 13534 & 8105 & 2802 & 3513 \\
\hline SD & 3186 & 13678 & 8964 & 3758 & 6198 & 863 & 1099 & 3145 \\
\hline $\mathrm{CV}$ & 9 & 44 & 34 & 43 & 46 & 11 & 39 & 90 \\
\hline
\end{tabular}

Source: Author's own calculation based on data contained in the financial statements of the concerned Indian automobile companies

Appendix 5

Growth of Capital employed (FBI) of Indian Automobile sector companies.

\begin{tabular}{|c|c|c|c|c|c|c|c|c|}
\hline Years & Tata & MSIL & $\mathrm{M} \& \mathrm{M} \mathrm{L}$ & Hero & Bajaj & Ashok & TVS & Eicher \\
\hline 2011 & 100 & 100 & 100 & 100 & 100 & 100 & 100 & 100 \\
\hline 2012 & 92 & 109 & 122 & 118 & 120 & 103 & 106 & 117 \\
\hline 2013 & 88 & 139 & 142 & 116 & 155 & 114 & 110 & 153 \\
\hline 2014 & 88 & 156 & 166 & 120 & 186 & 120 & 120 & 229 \\
\hline 2015 & 84 & 172 & 176 & 141 & 206 & 121 & 140 & 0 \\
\hline 2016 & 108 & 214 & 189 & 176 & 254 & 115 & 156 & 436 \\
\hline 2017 & 106 & 264 & 223 & 225 & 326 & 111 & 180 & 731 \\
\hline 2018 & 99 & 305 & 251 & 263 & 366 & 125 & 201 & 1008 \\
\hline 2019 & 108 & 339 & 282 & 287 & 417 & 138 & 256 & 1350 \\
\hline 2020 & 105 & 356 & 291 & 314 & 381 & 137 & 287 & 1570 \\
\hline Mean & 98 & 215 & 194 & 186 & 251 & 119 & 166 & 569 \\
\hline
\end{tabular}

Source: Author's own calculation based on data contained in the financial statements of the concerned Indian automobile companies 


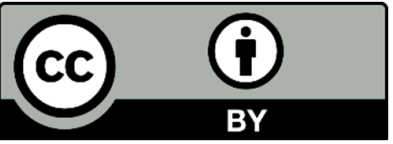

(C) 2022 by the authors; licensee Growing Science, Canada. This is an open access article distributed under the terms and conditions of the Creative Commons Attribution (CC-BY) license (http://creativecommons.org/licenses/by/4.0/). 